\title{
CURRENCY RISK MANAGEMENT PRACTICES BY AUSTRALIAN LISTED PROPERTY TRUSTS
}

\author{
GRAEME NEWELL and IAN MacINTOSH \\ University of Western Sydney
}

\begin{abstract}
Many Australian listed property trusts (LPTS) have significant levels of international property in their portfolios and have adopted a range of currency risk management strategies to mitigate some of this LPT risk due to their international property exposure. A survey of LPTS with international property is used to assess the characteristics of their international property portfolios and their currency risk management strategies for both capital and income risk management. In addition to the natural hedging strategies, increased use is being made of hedging procedures for both capital and income risk management. Different risk management strategies were also evident, depending on whether the LPT had a 100\% international property portfolio or a merged domestic/international property portfolio.
\end{abstract}

Keywords: Listed property trusts, international property, currency risk management, hedging strategies, capital component, income component

\section{INTRODUCTION}

With the global core investible property universe estimated to be US\$6.6 trillion (see Table 1) (Chen and Mills, 2006) and the global property market estimated to be US\$14.5 trillion (Hughes and Arissen, 2005), significant international property investment opportunities are available; particularly with Australia representing only $2 \%$ of the world's property markets. Recent years have seen international property investment take on increased importance, with the major contributing factors being the need for portfolio diversification, lack of local property investment opportunities, substantial growth in available investment funds, potential for higher returns, lower cost of capital and favourable exchange rates (Murdoch, 2004; Worzala and Newell, 1997). Improved maturity of some markets (eg: Asia) (Jones Lang LaSalle, 2006a), and improved market information and international communication via economic integration and deregulation have also contributed to reducing the costs and uncertainty associated with international property investment (Chen and Mills, 2004; McAllister, 1999; Murdoch, 2004). 
In the first half of 2006, international property investment accounted for US\$128 billion of the US $\$ 290$ billion in global commercial property transactions, with these cross-border property investments representing $44 \%$ of the total commercial property transactions in the first half of 2006. Importantly, $\$ 90$ billion (or 31\%) was cross-continent property investment (JLL, 2006b). This level of cross-border property investment was a $34 \%$ increase on the equivalent record level in the first half of 2005. Total 2006 international property investment is expected to be approximately US\$ 600 billion (JLL, 2006b).

While the portfolio diversification benefits of investing internationally for stocks and bonds have considerable historic evidence (eg: Odier and Solnick, 1993), considerable recent attention has also been given to assessing the portfolio diversification and riskreduction benefits of international property in a portfolio (eg: Addae-Dapaah and Loh, 2005; Chua, 1999; Conover et al, 2002; Eichholtz et al, 1998; Hoesli et al, 2004). Specific institutional investor practices regarding international property investment have also been assessed (eg: McAllister, 1999; Murdoch, 2004; Newell and Worzala, 1995; Worzala, 1994; Worzala and Newell, 1997). Recent reviews on international property investment include Sirmans and Worzala (2003), Wilson and Zurbruegg (2003) and Worzala and Sirmans (2003).

\section{Table 1: Leading international property markets $^{(1)}$}

\begin{tabular}{llll} 
US: & \$2,612 billion & Netherlands: & \$98 billion \\
Japan: & \$752 billion & Singapore: & \$94 billion \\
UK: & \$481 billion & Belgium: & \$63 billion \\
Germany: & \$453 billion & Sweden: & \$53 billion \\
France: & \$360 billion & Austria: & \$51 billion \\
Italy: & \$306 billion & Switzerland: & \$50 billion \\
Canada: & \$219 billion & Greece: & \$41 billion \\
Spain: & \$188 billion & Norway: & \$39 billion \\
South Korea: & \$182 billion & Denmark: & \$34 billion \\
Hong Kong: & \$150 billion & Portugal: & \$34 billion \\
Australia: & \$124 billion & Ireland: & \$31 billion \\
Taiwan: & \$116 billion & Finland: & \$30 billion \\
\hline
\end{tabular}

Source: Chen and Mills (2006)

1. All market values are given in US\$

However, international property investment introduces additional risk factors and barriers into the property investment process. These include currency risk, lack of local knowledge, ongoing property management/operational issues, liquidity risk, taxation differences, political risk, information costs, diversification costs and cultural factors (Chen and Mills, 2004, 2006; McAllister, 1999; Murdoch, 2004; Newell and Worzala, 1995; Worzala, 1994; Worzala and Newell, 1997). 
In particular, numerous studies have found that accounting for currency risk in international property investment significantly impacts on the resulting diversification benefits and risk profile (eg: Addae-Dapaah and Loh, 2005; Hoesli et al, 2004; Liu and Mei, 1998; Newell and Webb, 1996; Ziobrowski and Boyd, 1991; Ziobrowski and Curcio, 1991). Strategies to mitigate currency risk also figure prominently in institutional portfolio management (Chen and Mills, 2004; Murdoch, 2004; Newell and Worzala, 1995).

Given the importance of mitigating currency risk in international property investment, the purpose of this paper is to assess the level and location of international property in LPT portfolios and the significance of the currency risk management procedures utilised by listed property trusts (LPTs) in Australia for both capital and income risk management. This is particularly important given the increasingly high levels of international property in LPT portfolios in the US, Europe and Asia. This will be assessed using a survey of all LPTs in Australia, as well as a series of in-depth interviews with several LPT fund managers with significant international property portfolios.

\section{SIGNIFICANCE OF INTERNATIONAL PROPERTY IN LPTS}

Listed property trusts (LPTs) have been a mature, highly successful indirect property investment vehicle in Australia. The LPT sector has total assets of over $\$ 142$ billion, comprising over 3,000 institutional-grade properties in diversified and sector-specific portfolios (PIR, 2006a). At December 2006, LPTs had over $\$ 124$ billion in market capitalisation, representing over $9 \%$ of the total Australian stockmarket capitalisation (UBS, 2007). Table 2 lists the leading LPTs.

Table 2: Leading Australian LPTs: December 2006

\begin{tabular}{lcc}
\hline LPT & Market capitalisation & Property sector \\
\hline Westfield Group & $\$ 37.0$ billion & Retail \\
Macquarie Goodman Group & $\$ 12.6$ billion & Industrial \\
GPT Group & $\$ 11.4$ billion & Diversified \\
Stockland Trust Group & $\$ 11.3$ billion & Diversified \\
Centro Properties & $\$ 7.4$ billion & Retail \\
Mirvac Group & $\$ 5.4$ billion & Diversified \\
Investa Property Group & $\$ 3.8$ billion & Office \\
CFS Retail Trust & $\$ 3.1$ billion & Retail \\
Macquarie Office Trust & $\$ 3.0$ billion & Office \\
Macquarie CountryWide Trust & $\$ 2.6$ billion & Retail \\
\hline
\end{tabular}

Source: UBS (2007)

LPTs have performed strongly compared to the other major asset classes over the last ten years to December 2006(see Table 3), being the best performed sector over the 1,3, 5 and 10 -year holding periods. LPT risk levels (10.79\% over 1985-2005) are significantly below stockmarket risk (18.51\%) and only marginally above direct property risk (9.08\%) 
(IPD/PCA, 2006), reflecting the strong defensive characteristics of LPTs. Sector-specific LPTs have also typically outperformed the corresponding direct property sector over these various holding periods.

Table 3: Asset class performance: December 2006

\begin{tabular}{lcccc}
\hline \multirow{2}{*}{ Asset class } & $\mathbf{1 Y}$ & \multicolumn{4}{c}{ Average annual return (\%) } \\
& $17.3 \%(3)$ & $14.5 \%(3)$ & $13.0 \%(3)$ & $11.7 \%(3)$ \\
\hline Direct property & & & & \\
LPTs & $\mathbf{3 4 . 1 \% ( 1 )}$ & $\mathbf{2 5 . 9 \% ( 1 )}$ & $\mathbf{1 9 . 4 \% ( 1 )}$ & $\mathbf{1 6 . 1 \% ( 1 )}$ \\
Shares & $25.0 \%(2)$ & $24.5 \%(2)$ & $15.5 \%(2)$ & $13.1 \%(2)$ \\
Bonds & $2.5 \%(4)$ & $6.1 \%(4)$ & $5.6 \%(4)$ & $6.3 \%(4)$ \\
\hline
\end{tabular}

Source: IPD /PCA (2007)

${ }^{1}$ Rank amongst asset classes per time period given in brackets

With LPTs accounting for nearly $50 \%$ of all institutional-grade property in Australia, the lack of local property investment opportunities has seen LPTs seeking international property investments in recent years (Murdoch, 2004). Other motivating factors have been portfolio diversification benefits, growth in investment funds (via compulsory superannuation), better returns and lower cost of capital (Murdoch, 2004).

International property now accounts for over $35 \%$ of LPT total assets (Blundell, 2006; PIR, 2006b), having increased from only 5\% of LPT total assets in 1997 (Tan, 2004a, b). This now sees over 430 international properties in LPT portfolios, valued at over $\$ 40$ billion. Industry surveys indicate that these levels of international property are expected to increase to 50-60\% of LPT total assets by 2010 (Larsen, 2005; Norris, 2004; PIR, 2006b). While international property introduces the additional risk factors of currency risk, political risk and economic/investment risk, LPTs have typically used joint venture structures with local market participants as part of effective risk management strategies. The use of fractional interests for co-ownership of international properties has also been extensively used by LPTs in their risk management strategies (Newell and Tan, 2005). Typically, LPTs have used a more than $50 \%$ ownership structure for the property via a joint venture with a local player to retain management control of the international property asset. Importantly, the addition of international property to the LPT portfolio has been shown to give diversification gains (Tan, 2004a), as well as mixed-asset portfolio benefits (Tan, 2004b). 
In terms of performance, the international LPTs have shown strong performance over the 1, 3, 5 and 10-year holding periods, outperforming the overall LPT sector in the longer term over ten years (UBS, 2007) (see Table 4). Despite industry concerns that these increasing levels of international property could potentially result in higher risk levels (Oliver, 2004), this has not been the case for international LPTs or the overall LPT sector over the last ten years (Newell, 2006). The three-year rolling risk analysis in Figure 1 clearly demonstrates the stability in the international LPT risk profile since 2003, which coincides with the period of increased international property investment activity by LPTs (Newell, 2006). Similarly, a low correlation by international LPTs with the stockmarket was also evident on a rolling three-year basis (see Figure 2), reflecting continued portfolio diversification benefits by international LPTs (Newell, 2006). Whilst the small number of LPTs with international property in the early stages of this analysis may influence the respective risks and correlations achieved, subsequent years have seen a sufficient critical mass of these international LPTs to ensure reliable risk and correlation estimates.

Table 4: LPT performance analysis: December 2006

\section{LPT sectors}

\section{Average annual return $(\%)^{1}$}

\begin{tabular}{lcccc} 
& $\mathbf{1 Y}$ & $\mathbf{3 Y}$ & $\mathbf{5 Y}$ & $\mathbf{1 0 Y}$ \\
\hline LPTs & $34.1 \%$ & $25.9 \%$ & $19.4 \%$ & $16.1 \%$ \\
LPT sectors & & & & \\
Office & $28.4 \%(4)$ & $19.6 \%(6)$ & $13.0 \%(6)$ & $11.8 \%(6)$ \\
Retail & $28.1 \%(5)$ & $28.1 \%(2)$ & $20.5 \%(2)$ & $18.1 \%(3)$ \\
Industrial & $50.6 \%(1)$ & $36.2 \%(1)$ & $27.2 \%(1)$ & $20.4 \%(1)$ \\
Diversified & $39.3 \%(2)$ & $23.4 \%(4)$ & $19.4 \%(3)$ & $15.8 \%(4)$ \\
Stapled & $36.2 \%(3)$ & $21.4 \%(5)$ & $18.3 \%(4)$ & $14.4 \%(5)$ \\
securities & $22.7 \%(6)$ & $25.1 \%(3)$ & $17.5 \%(5)$ & $18.1 \%(2)$ \\
International & $22 \%$ & &
\end{tabular}

Source: UBS (2007)

${ }^{1}$ Rank amongst LPT sub-sectors per time period given in brackets

This performance analysis for international LPTs has seen stable risk profiles and low correlations with the stockmarket in recent years. This clearly highlights the overall effectiveness of the LPT risk management strategies adopted in mitigating some of the risk expected from exposure to international property. The following sections will specifically focus on assessing the international property portfolios and the currency risk management strategies used for capital and income risk management by those LPTs with international property in their portfolios. 


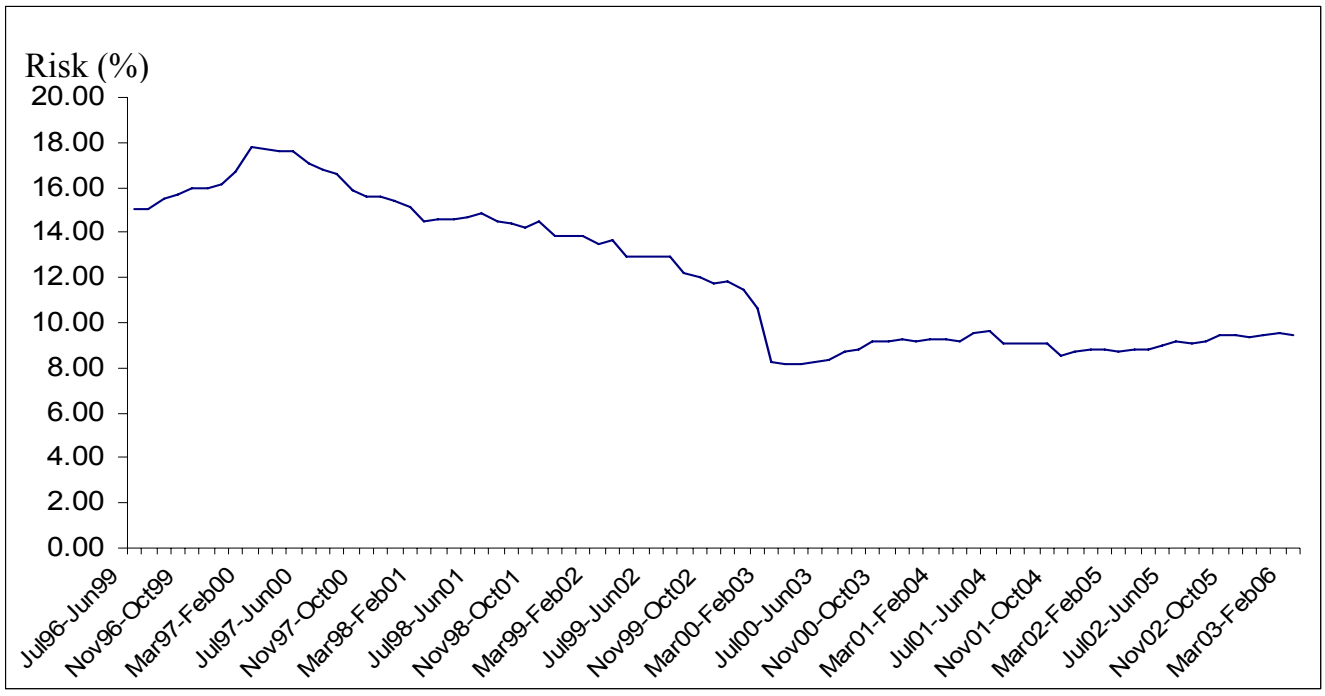

Source: Newell (2006)

Figure 2: Correlation profile of international LPTs and stockmarket: 1996 - 2006

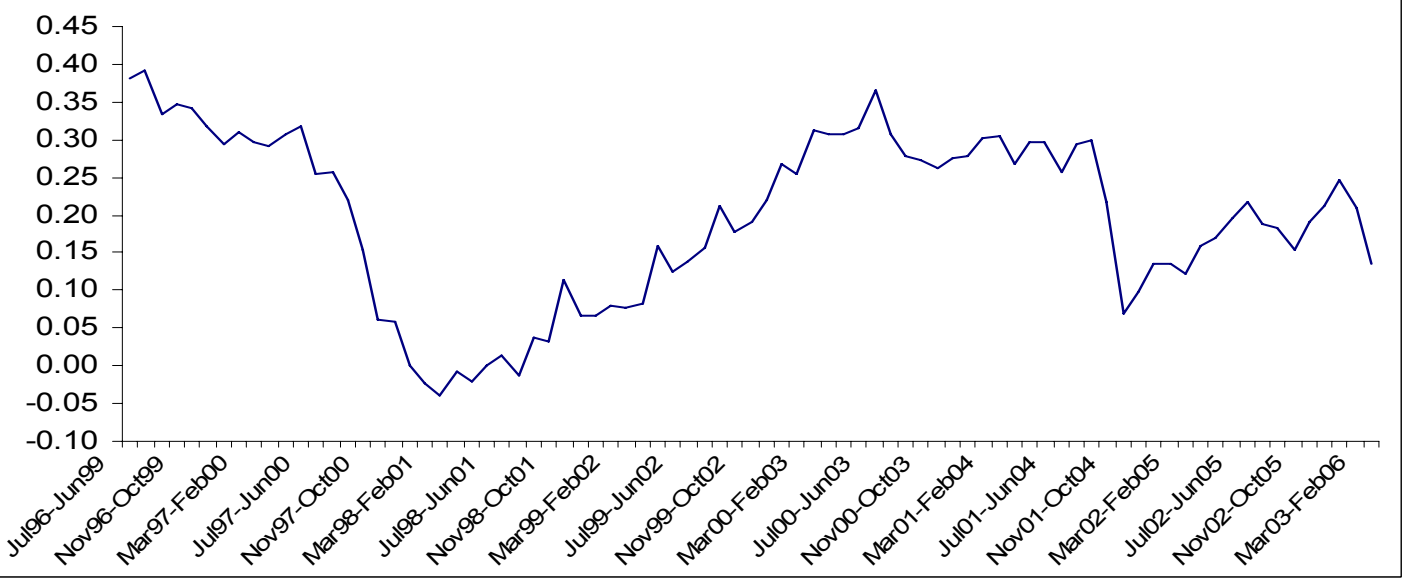

Source: Newell (2006) 


\section{CURRENCY RISK MANAGEMENT}

Given the importance of currency risk management (for both capital and income components) for international property investment, previous studies have identified the range of currency hedging techniques available (eg: Chen and Mills, 2004, 2006; Worzala, 1995); these include:

- forward contracts: agreement to exchange predetermined amount of currency in the future at a set date

- currency options: right (but not obligation) to exchange predetermined amount of currency in the future at a set date; typically expensive, with up-front payment needed

- currency swaps: agreement to exchange cashflows over time at a predetermined rate

- zero cost collars: involve sophisticated use of foreign exchange put and call options simultaneously.

The appropriateness of specific currency hedging techniques has also been assessed, including forward contracts (eg: Ziobrowski and Ziobrowski, 1995), currency options (eg: Ziobrowski and Ziobrowski, 1993) and currency swaps (eg: Johnson et al, 1998; Worzala et al, 1997; Ziobrowski et al, 1997). Other currency risk management strategies available (Chen and Mills, 2004, 2006; Newell and Worzala, 1995) are to increase gearing and borrow in local currency as a natural hedge, use local cashflow for interest payments, reinvest in same country, and diversify via establishing a global property portfolio.

Given the longer term nature of international property investment, currency swaps were seen to be more effective for currency risk management than the shorter-term currency options and forward contracts (Worzala et al, 1997; Ziobrowski et al, 1997). Issues regarding the significant cost of hedging and the effectiveness of capital hedging, given property's uncertain future value and longer holding period, have also been identified (Chen and Mills, 2006; Murdoch, 2004; Worzala, 1994, 1995). The impact of specific property asset risk is also an issue that distinguishes currency risk management for property hedging from general equities hedging. However, the potential need for less complex hedging strategies, given the more stable income stream from property, has been identified (Chen and Mills, 2004), as well as the lesser need for currency risk management resulting from regional economic integration (eg: Europe) (Chen and Mills, 2006).

Surveys of major institutional investors regarding the importance of currency risk management have seen considerable differences between perceived importance and risk management strategies adopted in different countries. In particular, a survey of Asia/Pacific international property investors (Newell and Worzala, 1995) saw currency risk as the major issue concerning international property investment, with $80 \%$ of respondents having currency risk management procedures. In contrast, a survey of 
European international property investors (Worzala, 1994) saw currency risk as the lowest priority issue, with only $20 \%$ of respondents having currency risk management procedures; in most cases, only for the income component of the international property investment. Typically, reasons cited for not using currency risk management strategies included the high cost of hedging, international property being too small a component in the total portfolio to justify hedging and the introduction of the Euro stabilising currency risk. However, given the increased significance of international property investment since these two previous surveys were conducted, a significantly increased focus on currency risk management is now expected. In particular, in a more recent survey of Australian international property investors (Murdoch, 2004), currency risk continued to be seen as a high priority risk factor, only exceeded by the accuracy of the property data available. Other risk factors to figure prominently were the availability of property data, high diversification costs and the depth of some property markets.

\section{METHODOLOGY}

The methodology used in this research was content analysis (Krippendorf, 2004). Content analysis (or textual analysis) is a standard methodology in the social sciences that systematically identifies the properties of textual information to describe and make inferences from the characteristics of a communication (eg: book, report, website). In this case, the LPT annual reports were utilised to assess the information disclosed regarding their international property portfolios and their currency risk management practices and procedures.

From the LPT listing in the UBS LPT monthly report (UBS, 2007) and a review of each of the LPT websites, 25 of the 57 LPTs in Australia were identified as having international property in their portfolios. These 25 LPTs with international property in their portfolios were then assessed for the nature of their international properties, with their 2005 annual reports examined for details of their international property portfolios and details regarding their currency risk management procedures for both capital and income risk management. LPT annual reports were chosen as the primary data source as they are public domain documents and represent the primary LPT vehicle for communicating with investors regarding their LPT investment strategy; specially their risk management procedures relating to currency risk management. This communication strategy was considered particularly important for those LPTs with merged domestic and international property portfolios, where international property represents a potential change in investment strategy, and investors need to be effectively informed of suitable risk management procedures regarding these international property investments being implemented by these LPTs.

In-depth interviews were also conducted for two LPTs with significant levels of international property in their LPT portfolios; namely Macquarie ProLogis Trust and 
Macquarie CountryWide Trust, representing LPTs with 100\% international and merged domestic/international property portfolios respectively. The detail provided by these interviews with the CEO of each of these LPTs provided specific and significant insights into current LPT market practices regarding currency risk management, with the findings integrated into the fuller content analysis of the LPT annual reports.

\section{RESULTS AND DISCUSSION}

\section{Profile of international property in LPTs}

With a total of 25 LPTs identified as having international property in their portfolios, international property has been included in these LPT portfolios as stand-alone international LPTs or merged with local property (see Table 5). In several cases, the merged domestic/international LPTs have in excess of $40 \%$ of the LPT property portfolio being international (eg: Macquarie CountryWide (74\%), ING Community Living (48\%), Westfield (45\%), Macquarie Office (60\%)), with most of these merged domestic/international LPTs having no international property in their portfolios when initially established. Amongst the thirteen "international-only" LPTs, eight have been established since only December 2004. 63\% of LPTs in the ASX300 now have international property in their portfolios (UBS, 2007). In addition to the office, retail and industrial sectors, some international LPTs have recently targeted the emerging retirement and student accommodation sectors (eg: ING Community Living via US properties) and the leisure sector (eg: Macquarie Leisure via US bowling centres). 
Table 5: LPTs with international property: December 2006

\begin{tabular}{lcc}
\hline LPT & $\begin{array}{l}\text { Property } \\
\text { sectors }\end{array}$ & $\begin{array}{l}\text { Market } \\
\text { capitalisa }\end{array}$ \\
\hline 100\% international portfolio (13 LPTs) & Retail & $\$ 164 \mathrm{M}$ \\
APN European Retail Trust & Diversified & $\$ 1,031 \mathrm{M}$ \\
Babcock \& Brown Japan PT & Retail & $\$ 1,198 \mathrm{M}$ \\
Galileo Shopping America Trust & Diversified & $\$ 295 \mathrm{M}$ \\
Galileo Japan Trust & Industrial & $\$ 381 \mathrm{M}$ \\
Mirvac Industrial Trust & Retail & $\$ 1,200 \mathrm{M}$ \\
Macquarie DDR Trust & Industrial & $\$ 1,081 \mathrm{M}$ \\
Macquarie ProLogis Trust & Diversified & $\$ 121 \mathrm{M}$ \\
Mariner American Property Income Trust & Office & $\$ 295 \mathrm{M}$ \\
Reckson NY Property Trust & Office & $\$ 454 \mathrm{M}$ \\
Rubicon America Trust & Office & $\$ 282 \mathrm{M}$ \\
Rubicon Europe Trust Group & Office & $\$ 192 \mathrm{M}$ \\
Rubicon Japan Trust & Office & $\$ 743 \mathrm{M}$ \\
Tishman Speyer Office Fund & &
\end{tabular}

\section{Merged domestic/international portfolio (12 LPTs)}

Centro Properties Group

Retail \$7,418M

DB RREEF Trust

Diversified $\$ 5,060 \mathrm{M}$

GPT

Diversified $\$ 11,433 \mathrm{M}$

ING Office Trust

Office $\$ 1,789 \mathrm{M}$

ING Industrial

Industrial $\$ 2,202 \mathrm{M}$

ING Community Living

Retirement \$390M

Macquarie CountryWide

Retail \$2,570M

Macquarie Goodman

Industrial $\$ 12,613 \mathrm{M}$

Macquarie Leisure

Leisure $\$ 630 \mathrm{M}$

Macquarie Office

Office $\$ 3,013 \mathrm{M}$

Stockland Trust Group

Diversified $\$ 11,330 \mathrm{M}$

Westfield Group

Retail \$36,982M

Source: UBS (2007) 
Table 6 presents the country/regional profile for these 25 LPTs with international property in their portfolios. Investment strategies were typically regionally-focused rather than trying to achieve global property portfolio diversification. Currency risk management is particularly important for these LPTs with a merged domestic/international portfolio, as these LPTs need to quarantine their international property risk component. This is particularly important as most of these merged portfolio LPTs did not have international property in their original portfolios; hence representing a change in their LPT investment strategy that needs to be effectively conveyed to their investors.

The initial focus for this international property investment by these 25 LPTs has been the US, with 16 of these 25 international property LPTs having significant levels of US property in their property portfolios (see Table 6). The main factors for the US being the primary off-shore market were existing market knowledge, developed market with sufficient depth, access to funding, depth of currency markets, incremental portfolio development, and ease of ongoing property and investment management. The US focus has recently expanded to Europe and Asia (see Table 6), reflecting increasing US interest rates and yield compression. In particular, a number of LPTs have been established in 2006, focusing on the Japanese property markets.

Over July 2005 - May 2006, of the $\$ 13$ billion in international property acquisitions by LPTs, the regional break-up was US (56\%), Europe/UK (35\%) and Asia (9\%) (Macquarie Research, 2006). These newer markets also present concerns; namely tightly held properties and the lesser yield gap in Europe and transparency issues in some Asian property markets (Blundell, 2006). Importantly, several of the Asian countries that have attracted international property investor interest (eg: Japan, Hong Kong and Singapore) have significantly enhanced the transparency of their property markets in the last ten years (JLL, 2006a). The successful establishment of REITs in Europe (eg: France, UK) and Asia (eg: Japan, Singapore, Hong Kong, Korea, Malaysia) is also expected to further increase property market transparency and increase Australian LPT investment interest in Europe and Asia. 
Table 6: Country profile for international LPTs : June 2006

\begin{tabular}{|c|c|c|c|c|c|}
\hline LPT & $\begin{array}{l}\text { Australian } \\
\text { assets }\end{array}$ & $\begin{array}{c}\text { US } \\
\text { assets }\end{array}$ & $\begin{array}{l}\text { European } \\
\text { assets }\end{array}$ & $\begin{array}{l}\text { Asian } \\
\text { assets }\end{array}$ & $\begin{array}{c}\mathrm{NZ} \\
\text { assets }\end{array}$ \\
\hline \multicolumn{6}{|l|}{$100 \%$ international portfolio (13 LPTs) } \\
\hline APN European Retail Trust & - & - & $100 \%$ & - & - \\
\hline Babcock \& Brown Japan PT & - & - & - & $100 \%$ & - \\
\hline Galileo Shopping America Trust & - & $100 \%$ & - & - & - \\
\hline Galileo Japan Trust & - & - & - & $100 \%$ & - \\
\hline Mirvac Industrial Trust & - & $100 \%$ & - & - & - \\
\hline Macquarie DDR Trust & - & $100 \%$ & - & - & - \\
\hline Macquarie ProLogis Trust & - & $100 \%$ & - & - & - \\
\hline Mariner American Property Income Trust & - & $100 \%$ & - & - & - \\
\hline Reckson NY Property Trust & - & $100 \%$ & - & - & - \\
\hline Rubicon America Trust & - & $100 \%$ & - & - & - \\
\hline Rubicon Europe Trust Group & - & - & $100 \%$ & - & - \\
\hline Rubicon Japan Trust & - & - & - & $100 \%$ & - \\
\hline Tishman Speyer Office Fund & - & $100 \%$ & - & - & - \\
\hline \multicolumn{6}{|c|}{ Merged domestic/international portfolio (12 LPTs) } \\
\hline Centro Properties Group & $67 \%$ & $30 \%$ & - & - & $3 \%$ \\
\hline DB RREEF Trust & $79 \%$ & $19 \%$ & - & - & $2 \%$ \\
\hline GPT & $73 \%$ & $4 \%$ & $23 \%$ & - & - \\
\hline ING Office Trust & $67 \%$ & $30 \%$ & $3 \%$ & - & - \\
\hline ING Industrial & $85 \%$ & - & $15 \%$ & - & - \\
\hline ING Community Living & $50 \%$ & $46 \%$ & - & - & $4 \%$ \\
\hline Macquarie CountryWide & $23 \%$ & $74 \%$ & - & - & $3 \%$ \\
\hline Macquarie Goodman & $93 \%$ & - & - & $4 \%$ & $3 \%$ \\
\hline Macquarie Office & $40 \%$ & $60 \%$ & - & - & - \\
\hline Macquarie Leisure & $87 \%$ & $12 \%$ & - & - & $1 \%$ \\
\hline Stockland Trust Group & $95 \%$ & - & - & - & $5 \%$ \\
\hline Westfield Group & $42 \%$ & $45 \%$ & $9 \%$ & - & $4 \%$ \\
\hline
\end{tabular}

Source: Authors' compilation from LPT annual reports 


\section{Exchange rate volatility}

Given the significant levels of international property in these LPT portfolios, currency risk management is important; particularly given the volatility in the Australian dollar exchange rates since 2000 (see Figures 3-5), which coincides with these significantly increased levels of international property acquisitions by LPTs. This period has seen considerable appreciation of the Australian dollar against the US dollar (see Figure 5) and would have resulted in a considerable loss regarding these US assets unless an effective currency risk management strategy had been implemented by the LPT. As such, a key objective for LPT currency risk management strategies is to reduce the volatility of earnings and the balance sheet associated with currency rate movements. This involves both income risk management (for profits generated offshore and repatriated) and capital risk management (for NAV fluctuations).

Figure 3: Exchange rate: \$AUS against \$US

(\$)

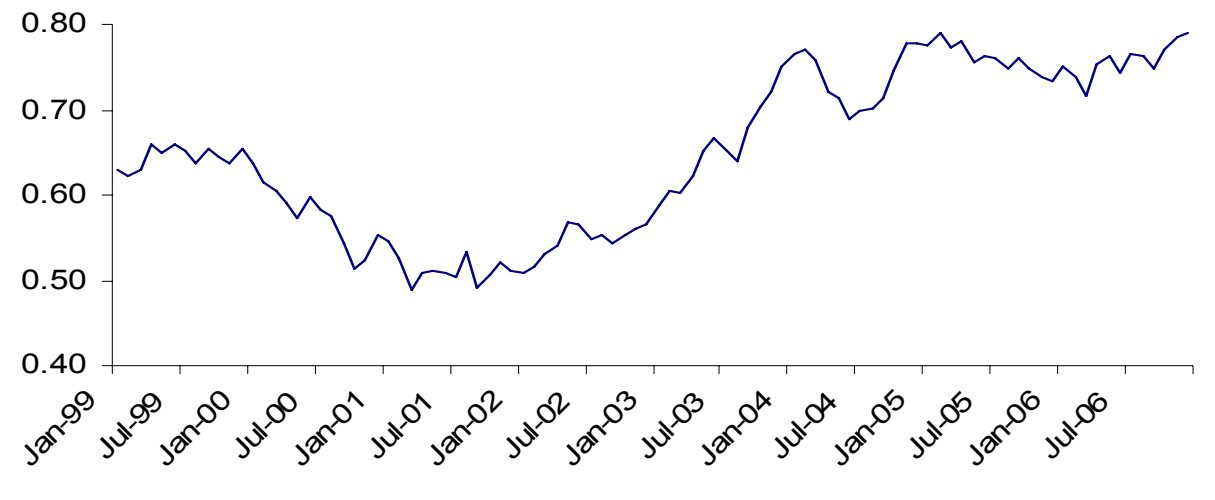

Source: Authors' compilation from RBA (2007) 
(\$)

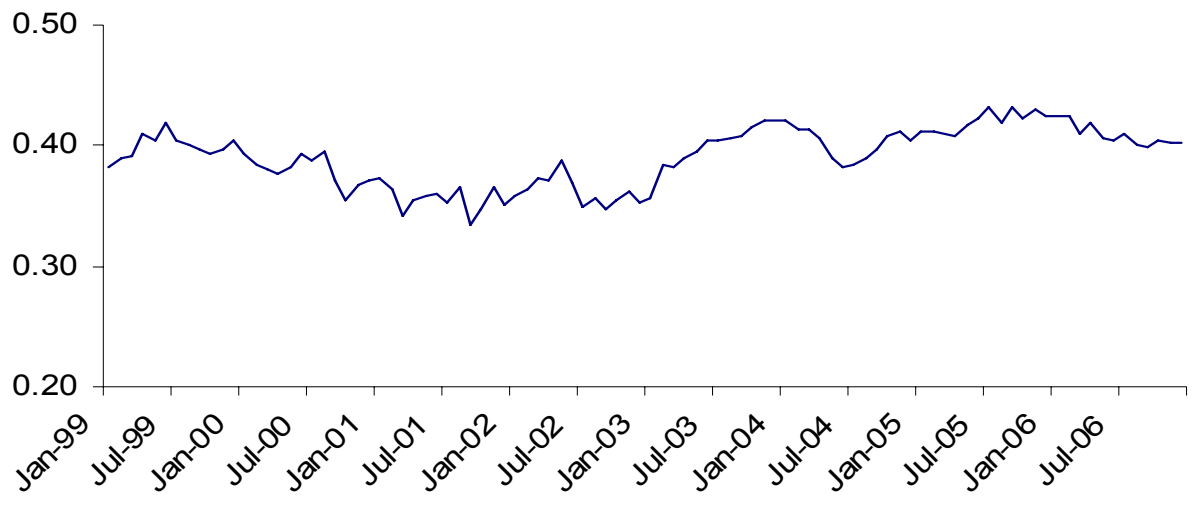

Source: Authors' compilation from RBA (2007)

Figure 5: Exchange rate: \$AUS against €EU

(\$)

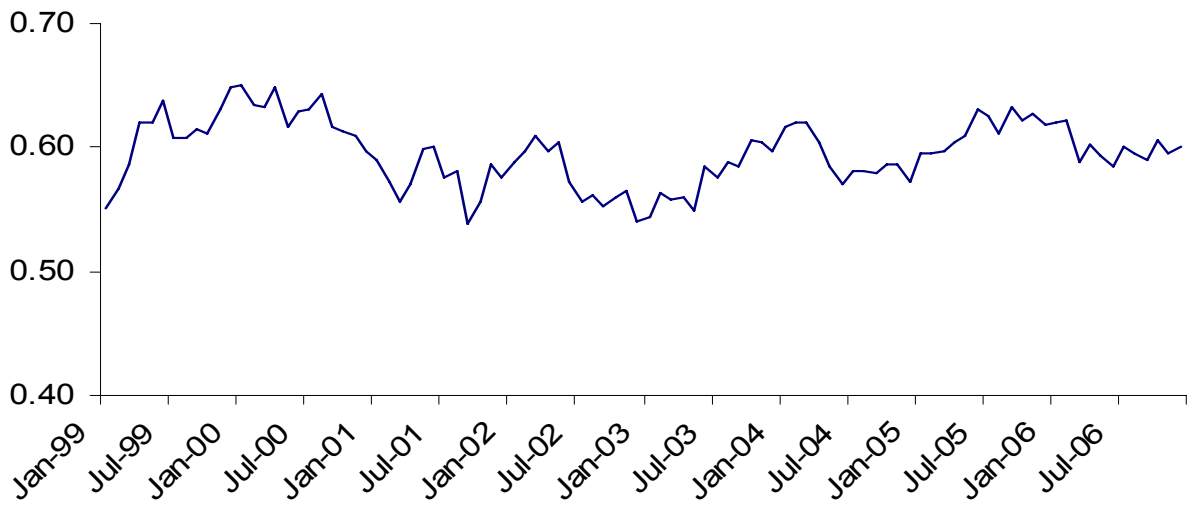

Source: Authors' compilation from RBA (2007) 
Using a survey of the 2005 annual reports of these LPTs and insights provided in interviews with two LPT fund managers with significant levels of international property in their LPT portfolios, the following sections identify the income risk management and capital risk management procedures utilised by the Australian LPTs in their currency risk management practices concerning international property investment.

\section{Income risk management}

Based on this survey, Table 7 provides details of the currency risk management strategies used by LPTs for the income component with these international property investments. All LPTs used a rolling currency hedging strategy for the forecast distributions from their international property investments. Most LPTs employed a $100 \%$ income hedge for 5 years of forecast distributions or a 100\% income hedge for the first 2-3 years of forecast distributions, reducing to a lower percentage hedge (not less than $50 \%$ of income hedged) for up to years 5-10.

\section{Table 7: Income risk management strategies by LPTs}

- Hedge 100\% for 5 years; eg: ING Office, Macquarie Office, APN European, Babcock \& Brown Japan, Macquarie CountryWide

- Hedge 100\% for 7 years; eg: Rubicon Europe, Rubicon America

- Hedge $100 \%$ for 3 years; reducing to lower percentage (eg: $50 \%$ ) up to 10 years; eg: Galileo, Centro, Reckson NY

- Hedge $100 \%$ for 2 years; then lower percentage (eg: 80\%, 90\%) for years 3-5; eg: Macquarie DDR, Macquarie ProLogis, GPT

- Hedge up to $100 \%$ for 3 years; eg: Westfield

- Hedge at least $90 \%$ for 1 year; to minimum of 50\% in year 5; eg: Tishman Speyer Office

Source: LPT annual reports, Macquarie Research (2006)

Typical income risk management hedging strategies for specific LPTs included:

- $100 \%$ international portfolio

- Galileo Shopping America: 89\% hedged for average of 6.6 years

- Macquarie DDR: 77\% hedged for average of 4.4 years

- Macquarie ProLogis: $81 \%$ hedged for average of 3.9 years

- Tishman Speyer Office: $94 \%$ hedged for average of 7.4 years

- merged domestic/international portfolio

- DB RREEF: $90 \%$ hedged for average of 6.4 years

- ING Office: $65 \%$ hedged for average of 2.4 years

- Macquarie CountryWide: $77 \%$ hedged for average of 4.4 years 
- Macquarie Office: $86 \%$ hedged for average of 5.5 years

- Westfield: $84 \%$ hedged for average of 7.7 years.

On a weighted average basis, LPTs were approximately $75 \%$ income hedged for 5.9 years in 2006 (Macquarie Research, 2006); further reinforcing the high priority given to income risk management by these LPTs. This saw most LPTs suitably hedged for forecast distributions until approximately 2010, with future income hedging likely to be significantly influenced by increasing US interest rates. Confidentiality requirements precluded details being provided regarding the cost of these income risk management strategies.

Most LPTs would also periodically implement additional income hedges to maintain a relatively consistent hedge profile; particularly as forecast distributions become more firm. This income hedging strategy was generally achieved by forward contracts, with incremental additions to existing forward contracts not seen as expensive in better managing their exposure, as forecast distribution cashflows are known with more certainty.

The natural hedge of offsetting foreign debt was also utilised, with LPTs with international property typically having higher gearing levels in US dollars. The average gearing levels were found to be:

- $100 \%$ international: $52 \%$; ranging from $31 \%-71 \%$

- merged domestic/international: 33\%; ranging from $17 \%-41 \%$

- $100 \%$ domestic: $32 \%$; ranging from $13 \%-45 \%$,

with several international LPTs having 100\% US debt (eg: Galileo Shopping America, Macquarie DDR, Macquarie ProLogis, Tishman Speyer Office) and others having in excess of $60 \%$ US debt (eg: Macquarie CountyWide, Westfield).

\section{Capital risk management}

Whilst the use of income hedging was extensive and generally consistent across the LPTs investing in international property, the use of capital hedging has taken on increased use recently to reduce NTA volatility for LPTs. Capital hedging is more important for the merged domestic/international LPTs to quarantine their international property exposure. Some degree of uncertainty is evident in the capital hedging process as LPTs are not finite life property investment vehicles and their international property investments are not made for pre-determined holding periods, resulting in an inability to exactly match the term of the capital risk and the selected hedging vehicle.

Based on this survey, Table 8 provides details of the currency risk management strategies used by LPTs for the capital component with these international property investments. Management of this capital risk was most evident by the natural hedge of offsetting 
overseas assets and liabilities (via maximised US dollar borrowings); particularly for merged domestic/international LPTs, with a full offset not available to $100 \%$ international LPTs due to the loan-to-value borrowing restrictions (typically 65\%) on international assets. Given the need to quarantine their international property exposure from their domestic property exposure, a number of merged domestic/international LPTs hedged $100 \%$ of their overseas capital exposure (eg: Macquarie CountyWide, Macquarie Office). $100 \%$ international LPTs typically only employed a partial capital hedging strategy; eg: Babcock \& Brown Japan (20\%), Macquarie ProLogis (45\%), Macquarie DDR (45\%), with future expectations to significantly increase these levels of partial hedging (eg: Macquarie ProLogis). Several LPTs explicitly stated that they would not undertake capital hedging; eg: APN European, Reckson NY.

\section{Table 8: Capital risk management strategies by LPTs}

- Match overseas assets and liabilities; eg: Centro, GPT, ING Office, Westfield, Macquarie Office, Macquarie CountryWide

- $\quad 100 \%$ capital hedge; eg: Macquarie CountryWide, Macquarie Office

- Partial capital hedge; eg: Babcock \& Brown Japan, Macquarie ProLogis, Macquarie DDR

Source: LPT annual reports, Macquarie Research (2006)

Cross currency swaps were the most frequently used capital hedging strategy vehicles; eg: Babcock \& Brown Japan, Macquarie CountryWide, Macquarie DDR, Macquarie Office, Macquarie ProLogis; confirming previous research on the most effective capital risk management strategy (Johnson et al, 1998; Worzala et al, 1997; Ziobrowski et al, 1997). Specific cross currency swaps implemented for capital hedging (Macquarie Research, 2006) include:

- Macquarie CountryWide: US\$ 867M; average term to maturity of 3.9 years

- Macquarie DDR: US\$100M; average term to maturity of 5.0 years

- Macquarie Office: US\$363M; average term to maturity of 3.7 years

- Macquarie ProLogis: US\$ 340M; average term to maturity of 5.5 years.

Zero cost collars (eg: Rubicon Europe) and forward contracts (eg: Macquarie CountryWide, Macquarie ProLogis) were also seen to have been used as capital hedging procedures by these international property LPTs, but less frequently than cross currency swaps. Confidentiality requirements precluded details being provided regarding the cost of these capital risk management strategies.

\section{Investor communication regarding currency risk management}

The annual report is the most effective communication strategy for LPTs to advise investors of their investment strategy and risk management procedures. The level of detail provided in these LPT annual reports regarding the LPT currency risk management 
procedures has increased significantly in recent years; particularly as it involves international property investment which is often perceived as higher risk. This level of detail was generally more extensive amongst the more recently established $100 \%$ international LPTs and certain merged domestic/international LPTs (eg: Macquarie CountryWide).

\section{CONCLUSION}

Overall, property is a long-term investment, with the primary longer-term motivation being property market expectations not currency fluctuations (Chen and Mills, 2006). Similarly, currency fluctuations can work in favour of the LPT to generate additional income repatriation from these international property investments (Chen and Mills, 2006). However, given the increasingly significant level of international property in LPT portfolios, currency risk management has taken on increased importance for both income and capital risk management.

This survey has identified a range of hedging strategies being used by LPTs to manage currency risk for their international property portfolios, including natural hedging strategies and the increased use of currency forwards (income component) and cross currency swaps (capital component), with an increased recent focus on capital risk management. The diversity of currency risk management procedures used is also influenced by how international property is structured in the LPT portfolio; either as $100 \%$ international or merged domestic/international portfolios. To date, LPTs have adopted effective currency risk management strategies; however, ongoing active currency risk management for these LPTs will be increasingly important for LPTs to accommodate higher US interest rates, as well as the need for increased diversification into the expanding European and Asian property markets; particularly as the level of international property in LPTs is expected to increase to $50 \%-60 \%$ by 2010 .

\section{REFERENCES}

Addae-Dapaah, K. and Loh, H.L. (2005), Exchange rate volatility and international real estate diversification: a comparison of emerging and developed economies. Journal of Real Estate Portfolio Management 11(3):225-240.

Blundell, L. (2006), Safe as houses? Property Australia 20(6):22-25.

Chen, L. and Mills, T. (2004), Global real estate investment goes mainstream. UBS.

Chen, L. and Mills, T. (2006), Global real estate investment: the world is becoming flatter. UBS. 
Chua, A. (1999), The role of international real estate in global mixed-asset investment portfolios. Journal of Real Estate Portfolio Management 5(2):129-137.

Conover, C., Friday, H. and Sirmans, G. (2002), Diversification benefits from foreign real estate investments. Journal of Real Estate Portfolio Management 8(1):17-25.

Eichholtz, P., Huisman, R., Koedijk, K. and Schuin, L. (1998), Continental factors in international real estate returns. Real Estate Economics 26:493-510.

Hoesli, M., Lekander, J. and Witkiewicz, W. (2004), International evidence on real estate as a portfolio diversifier. Journal of Real Estate Research 26(2): 165-206.

Hughes, F. and Arissen, J. (2005), Global real estate securities-where do they fit in the broader market. EPRA News (Dec.): 18-21.

IPD/PCA (2007), Investment Performance Index: December 2006. IPD/PCA, Melbourne.

Johnson, R., Lizieri, C. and Worzala, E. (1998), Currency swaps for hedging a realistic international real estate investment: do they work? RICS Research Series.

Jones Lang LaSalle (2006a), Real estate transparency index. JLL, Chicago.

Jones Lang LaSalle (2006b), Global real estate capital: record volumes, record globalisation. JLL, London.

Krippendorf, K. (2004), Content Analysis: An Introduction to its Methodology. Sage, California.

Larsen, C. (2005), The Big Think: predicting the future for property. Property Australia 20(1):54-55.

Liu, C. and Mei, J. (1998), The predictability of international real estate markets: exchange rate risk and diversification opportunities. Real Estate Economics 26:3-39.

Macquarie Research (2006), Listed property trusts. Macquarie Research (May).

McAllister, P. (1999), Globalisation, integration and commercial property. Journal of Property Investment and Finance 17:8-26.

Murdoch, J. (2004), The globalisation of Australian LPTs. Australian Property Journal 38:5-12. 
Newell, G. (2006), The changing risk profile of listed property trusts. Australian Property Journal 39(3): 172-180.

Newell, G. and Tan, Y. K. (2005), The significance of fractional interests in LPT portfolios. Pacific Rim Property Research Journal 11(3):282-298.

Newell, G. and Webb, J. (1996), Assessing risk for international real estate investments. Journal of Real Estate Research 11(2):103-115.

Newell, G. and Worzala, E. (1995), The role of international property in investment portfolios. Journal of Property Finance 6:55-63.

Norris, S. (2004), Exploring the LPT landscape. Property Australia 18(9):54-56.

Odier, P. and Solnick, B. (1993), Lessons for international asset allocation. Financial Analysis Journal (March):63-77.

Oliver, S. (2004), LPT changes-implications for investors. Property Australia 19(1):106107.

Property Investment Research (2006a), Australian Property Funds Industry Survey: 2006. PIR, Melbourne.

Property Investment Research (2006b), LPT Monthly Review (miscellaneous copies). PIR, Melbourne.

Reserve Bank of Australia (2007), Reserve Bank "Bulletin". RBA, Sydney.

Sirmans, C. F. and Worzala, E. (2003), International direct real estate investment: a review of the literature. Urban Studies 40:1081-1114.

Tan, Y. K. (2004a), Benchmarking international property in Australian listed property trust portfolios. Pacific Rim Property Research Journal 10(1):3-29.

Tan, Y. K. (2004b), The role of international property trusts in Australian mixed-asset portfolios. Pacific Rim Property Research Journal 10(2):215-234.

UBS (2007), UBS indices: December 2006. UBS, Sydney.

Wilson, P. and Zurbruegg, R. (2003), International diversification of real estate assets: is it worth it? Evidence from the literature. Journal of Real Estate Literature 11(3):259-277. 
Worzala, E. (1994), Overseas property investments: how are they perceived by the institutional investors. Journal of Property Valuation and Investment 12:31-47.

Worzala, E. (1995), Currency risk and international property investments. Journal of Property Valuation and Investment 13(5):23-28.

Worzala, E., Johnson, R. and Lizieri, C. (1997), Currency swaps as a hedging technique for an international real estate investor. Journal of Property Finance 8:134-151.

Worzala, E. and Newell, G. (1997), International real estate: a review of strategic investment issues. Journal of Real Estate Portfolio Management 3(2):87-96.

Worzala, E. and Sirmans, C. F. (2003), Investing in international real estate stocks: a review of the literature. Urban Studies 40: 1115-1149.

Ziobrowski, A. and Boyd, J. (1991), Leverage and foreign investments in US real estate. Journal of Real Estate Research 7(1):33-58.

Ziobrowski, A. and Curcio, R. (1991), Diversification benefits of US real estate to foreign investors. Journal of Real Estate Research 6(2): 119-142.

Ziobrowski, A. and Ziobrowski, B. (1993), Hedging foreign investments in US real estate with currency options. Journal of Real Estate Research 8(1):27-54.

Ziobrowski, A. and Ziobrowski, B. (1995), Using forward contracts to hedge foreign investment in US real estate. Journal of Property Valuation and Investment 13(1):22-43.

Ziobrowski, A., Ziobrowski, B. and Rosenberg, S. (1997), Currency swaps and international real estate investment. Real Estate Economics 25:223-252. 